\title{
Types of knowledge and diversity of business-academia collaborations: implications for measurement and policy
}

Attila Havas (1)

Correspondence: attila.havas@krtk.
mta.hu
Institute of Economics, Centre for
Economic and Regional Studies,
Hungarian Academy of Sciences,
Budaorsi ut 45., Budapest, Hungary

\begin{abstract}
Analysis of business-academia (B-A) collaborations typically relies on a single method, addressing one or two major research questions. In contrast, this article tackles both research and development (R\&D) and innovation collaborations among businesses and academia relying on information using multiple methods and multiple sources of information to offer insights on dynamics and qualitative features of these co-operation processes. Interviews conducted in Hungary —in line with other research findings-have also confirmed that (i) motivations, incentives for, and norms of conducting R\&D and innovation activities diametrically differ in business and academia; and (ii) different types of firms have different needs. Thus, more refined policy measures are to be devised to promote B-A collaboration more effectively, better tuned to the needs of the actors, based on a relevant taxonomy of their co-operations. Evaluation criteria for academics should also be revised to remove some major obstacles, currently blocking more fruitful B-A co-operation. Several findings can be generalised beyond the cases considered, suggesting the need for a deeper understanding of the role of intermediaries in the Triple Helix and for broader comparative analysis of innovation policies. The research design to analyse B-A collaborations always needs to be tailored to the innovation system in question, just as the concomitant policy recommendations.
\end{abstract}

JEL Classification: $\mathrm{O} 38 ; \mathrm{O} 33$

Keywords: Types of knowledge; Diversity in business-academia collaboration; Multiple methods to map business-academia collaborations; STI policy implications

Spanish: Tipos de conocimiento y diversidad de las colaboraciones industria-academia: Implicaciones para indicadores cuantitativos y políticas públicas.

Resumen: El análisis de colaboraciones industria-academia (I-A) depende típicamente de un solo método. En cambio, este artículo estudia inversiones en I\&D (investigación y desarrollo) y colaboraciones I-A usando múltiples métodos y múltiples fuentes de información. El artículo ofrece ideas sobre la dinámica y las características medibles de esas colaboraciones.

Las entrevistas conducidas en Hungaria-en línea con otros resultados de investigación-confirman que (i) motivaciones, incentivos, y normas, en la realización de I-A y otras actividades de innovación difieren diametralmente entre la industria y la academia; y (ii) diferentes tipos de firmas tienen diferentes necesidades.

(Continued on next page)

\section{Springer}

(c) 2015 Havas. This is an Open Access article distributed under the terms of the Creative Commons Attribution License (http:// creativecommons.org/licenses/by/4.0), which permits unrestricted use, distribution, and reproduction in any medium, provided the original work is properly credited. 
(Continued from previous page)

Por tanto, las políticas públicas deben refinarse para promover colaboraciones I-A más efectivas y más acorde con las necesidades de los actores de innovación. Estas políticas deben basarse en una taxonomía relevante del tipo de colaboraciones. Criterios evaluativos de las universidades deben también revisarse para levantar obstáculos a la formación de cooperaciones industria-universidad.

Nuestros resultados no deben generalizarse más allá de los casos considerados y sugieren la necesidad de un entendimiento más profundo del rol de los intermediarios en la Triple Hélice y por un análisis comparativo más amplio de políticas de la innovación.

French: Types de connaissance et diversité de collaborations entreprises-universités : implications en termes de mesure et de politique

Résumé: L`analyse de la collaboration entreprises-universités repose généralement sur une seule méthode, et n'aborde qu'une ou deux grandes questions de recherche. En revanche, cet article s'intéresse à la fois à la R\&D et aux collaborations dans le domaine de l'innovation entre les entreprises et les universités en utilisant diverses méthodes d'analyse et de multiples sources d'information pour offrir un aperçu de la dynamique et des aspects qualitatifs de ces processus de coopération. Des entretiens menés en Hongrie - ainsi que d'autres résultats de recherche - ont aussi confirmé que (i) les motivations, les incitations et les normes pour développer la R\&D et les activités d'innovation diffèrent diamétralement dans les entreprises et les universités ; et (ii) des types différents d'entreprises ont des besoins différents. Ainsi, des politiques de développement plus fines ont besoin d'être mises en place pour favoriser des collaborations plus efficaces, mieux adaptées aux besoins des acteurs, fondées sur une taxonomie pertinente de leurs coopérations. Les critères d'évaluation des universités devraient aussi être révisés afin de lever quelques obstacles majeurs, qui bloquent à l'heure actuelle une coopération entreprises-universités plus fructueuse. Plusieurs conclusions peuvent être généralisées au-delà des cas considérés, et évoquent la nécessité d'une meilleure compréhension du rôle des intermédiaires dans la Triple Hélice et d'analyses comparatives élargies des politiques d'innovation. La recherche et les analyses des collaborations entreprises-universités doivent toujours être adaptées aux systèmes d'innovation en question, tout comme les recommandations politiques afférentes.

Chinese: 知识类型和产学合作的多样性: 对测量和政策的影响

摘 要: 产学(B-A)合作分析通常依赖某个单一的方法, 解决一两个主要的研究问 题。与此相反, 本文抓住产业和学术界之间的研发和创新合作, 依靠利用多种方 法和多个来源获得的信息, 提供对这些合作过程的动力和定性特征的见解。在匈 牙利所进行的访谈与其他研究结果共同证实:

(I) 在产业和学术界进行研发和创新活动的动机和规范截然不同; (ii) 不同类型的 公司有不同的需求。因此, 为了促进更有效的产学合作, 基于对于它们合作的相 关分类，更精致的政策措施将被设计，以更好地满足（研发和创新）主体的需要。 此外, 为了消除目前妨碍更有效产学合作的某些主要障碍, 学术评价标准也应该 被修改。除了这些考虑到的情况外, 几个研究结果可以被概括为: 我们需要对三 螺旋中介机构的作用有更深入的认识和理解, 需要对创新政策进行更广泛的比较 分析; 对于分析产学合作的研究设计总是要适合于特定创新体系中的问题, 正如 总是要伴随政策建议一样。 
Russian: Типы знаний и разнообразие взаимосвязей бизнес-университет: значение для оценки и политики

Анотация: Анализ взаимоотношений Бизнеса и Науки (business-academia, далее B-A) обычно основывается на одном методе, который дает ответ на один или два главных вопроса в рамках исследования. Напротив, настоящая статься соединяет воедино исследования и разработки с инновационными взаимодействиями между бизнесом и наукой, опираясь на различные методы и источники информации, предоставляя данные о динамике и качественных характеристиках кооперации. В ходе проведения интервью в Венгрии - помимо прочих результатов исследования - было также подтверждено, что (i) мотивация, стимулирование и стандарты проведения исследований и разработок и инновационной активности диаметрально отличаются для науки и бизнеса; и (ii) различные типы фирм имеют различные потребности. Следовательно, требуется разработка более точных программных мероприятий для повышения эффективности взаимодействия В-А, полнее учитывающих потребности участников, основанных на релевантной классификации их взаимоотношений. Оценочные критерии для сферы науки предполагают дополнительный пересмотр с целью исключения некоторых значимых ограничений, блокирующих на данном этапе более продуктивные взаимосвязи В - А. Некоторые результаты вынесены отдельно от рассмотренных примеров, т.к. требуют более глубокого изучения роли промежуточных участников в Тройной Спирали и проведения более широкого сравнительного анализа инновационных стратегий. Любое исследование, посвященное взаимодействиям В - A, всегда должно быть адаптировано к инновационной системе, давая сопутствующие рекомендации к реализуемым стратегиям.

Portuguese: Tipos de conhecimento e diversidade de colaborações universidadeempresa: implicações para mensuração e políticas.

Resumo: A análise das colaborações entre universidade e empresa (U-E) normalmente utilizam um único método, baseado em uma ou duas questões de pesquisa. Diferentemente, este artigo aborda tanto as colaborações de P\&D quanto as colaborações inovadoras entre universidade e empresa, utilizando diversos métodos e fontes de informação para oferecer insights acerca da dinâmica e das características qualitativas desses processos. Em entrevistas realizadas na Hungria, bem como em outros resultados de pesquisa, confirmaram que (i) as motivações, os incentivos e as normas de condução das atividades de P\&D e de inovação diferem diametralmente na colaboração entre universidade e empresa; e (ii) diferentes tipos de empresas possuem diferentes necessidades. Deste modo, medidas políticas mais refinadas devem ser concebidas para promover a colaboração universidade e empresa de forma mais eficaz, e mais sintonizada com as necessidades dos atores, levando-se em conta uma taxonomia relevante dessas cooperações. O critério de avaliação para as universidades deveria ser também revisto de modo a retirar alguns dos principais obstáculos que atualmente bloqueiam uma cooperação U-E mais frutífera. Diversos resultados podem ser generalizados além dos casos considerados, sugerindo a necessidade de uma compreensão mais profunda do papel dos intermediários dentro da Hélice Tríplice, bem como uma análise comparativa mais ampla de políticas de inovação. O projeto de pesquisa voltado para a análise das colaborações entre universidade e empresa sempre necessitam ser adaptados para o sistema de inovação em questão, assim como as respectivas recomendações políticas. 


\section{Multilingual abstract}

Please see Additional file 1 for translation of the abstract into Arabic.

\section{Introduction}

Innovation has become a paramount issue to economists of all stripes, irrespective of their main research questions and preferred methods, e.g. econometrics, game theoretical models, simulations, controlled experiments or qualitative analyses. Technological, organisational, managerial changes and opening up new markets-that is, all sorts of innovation using modern terminology - had been a major theme in classical economics. Then neoclassical (general equilibrium) economics essentially abandoned research questions concerned with dynamics, and instead focused on static comparative analyses and optimisation. Technological changes were treated as exogenous to the economic system. More recently, given compelling empirical findings and new theoretical insights on firm behaviour and the operation of markets, various branches of mainstream economics ${ }^{1}$ have relaxed some of the most unrealistic assumptions of neoclassical economics, and put innovation back on the research agenda.

For evolutionary economics of innovations, in contrast, since its foundation innovation has been the central theme, and this paradigm has also developed a diametrically different theoretical framework to analyse its core questions. These competing schools, however, now share some major claims: innovation contributes to enhanced productivity to a decisive extent, creates new opportunities to increase profits, and thus improves competitiveness at the micro level. Further, it has significant impacts on several macroeconomic indicators, too, including growth, the structure of the economy and foreign trade, balance of payment, investments and employment. ${ }^{2}$ These schools, although consider different types of knowledge as major inputs for innovations, also share the view that universities and publicly financed research organisations (PROs) are major actors.

There are a variety of linkages in a successful national innovation system (NIS) among its players (businesses, academia, intermediary organisations, service providers, policy-makers etc.). The types and quality of links between these actors influence the performance of a given NIS, just as external linkages, that is, the internationalisation of research, technological development and innovation (RTDI) processes and the impacts of external STI policies. Of these linkages, only business-academia (B-A) co-operation is discussed in this paper. It is aimed at providing a map of business-academia collaboration in the EU countries, drawn by using several 'lenses' offered by various data sets, together with findings of interviews conducted with firms in Hungary. It should be stressed, though, that it is rather an essay-drawing on several projects analysing various aspects of innovation processes-to highlight the need for multi-source, multi-method analyses of business-academia collaboration and a new way of policy thinking than a 'standard' article summarising the results of a specific research project, tackling particular research questions defined at the outset.

The article is organised as follows. Section 2 highlights different types of knowledge, stemming from various sources, required for successful innovation processes, and juxtaposes various models of innovation and economics paradigms as to how these various approaches treat knowledge created and used for innovation and hence what type of B-A collaborations attract their attention. Section 3 briefly describes the major RTDI performing sectors in $24 \mathrm{EU}$ countries, then explores B-A co-operation from several angles, relying on various sets of statistics. Section 4, based on interviews with firms 
operating in Hungary, argues that different types of firms have different types of needs and internal resources, and thus they enter into different types B-A co-operations. Further, businesses and academic organisations have different motivations for co-operation, as well as different norms, values and internal decision-making systems, and thus co-operation is far from being smooth. Conclusions, policy implications and directions for further research are summarised in Section 5.

\section{Types of knowledge in innovation models and economics paradigms}

\subsection{Linear, networked and multi-channel interactive learning models of innovation}

The idea that basic research is the main source of innovation was already advanced in the beginning of the twentieth century, mainly by natural scientists and managers of company labs who were comparing large firms, business sectors and national economies by their research and development (R\&D) intensities in an attempt to establish the links between R\&D activities and economic performance (Fagerberg et al. 2011; Godin 2008). This reasoning then became a key idea in Bush (1945), a still highly influential report. Bush was the first policy advisor who forcefully explained the fundamental role of scientific research in underpinning economic competitiveness and advocated a new line in policy thinking:

'We will not get ahead in international trade unless we offer new and more attractive and cheaper products. New products and new processes do not appear full-grown. They are founded on new principles and new conceptions, which in turn are painstakingly developed by research in the purest realms of science. (...) In the nineteenth century, Yankee mechanical ingenuity, building largely upon the basic discoveries of European scientists, could greatly advance the technical arts. Now the situation is different. A nation which depends upon others for its new basic scientific knowledge will be slow in its industrial progress and weak in its competitive position in world trade, regardless of its mechanical skill.' (Bush 1945, ch. 3)

Bush emphasised that the US could no longer rely on application of knowledge discovered abroad but must pay increased attention to discovering this knowledge as basic research is the ultimate source of technological progress. 'For many years the Government has wisely supported research in the agricultural colleges and the benefits have been great. The time has come when such support should be extended to other fields.' (ibid.)

Then the classic articles on the 'simple economics of basic scientific research' by Nelson (1959) and the 'allocation of resources for invention' by Arrow (1962) marked a new beginning. Since then various economics schools have also applied and adapted their own analytical tools and methods to examine various aspects of RTDI processes, and a new paradigm, namely the evolutionary economics of innovation has also 'evolved'. 3

These ideas have gradually led to what is known today as the science-push model of innovation. By the second half of the 1960s, the so-called market-pull model contested that reasoning, portraying demand as the driving force of innovation. An extensive debate has evolved between these two approaches, trying to establish which is more accurate in describing innovation processes, and especially identifying the most important information sources for innovation. ${ }^{4}$ Then both became variants of the linear model of innovation when Kline and Rosenberg (1986) suggested the chain-linked model, stressing the non-linear property of innovation processes, the variety of sources of information, as well as the 
importance of various feedback loops. This latter one has been extended into the networked model of innovation; more recently called the multi-channel interactive learning model (Caraça et al. 2009).

In sum, both the science-push and the networked (interactive) models of innovation emphasise the role of universities and PROs as important information sources for innovation. The main difference between these approaches is how they portray the other actors: the networked model considers various types of knowledge-besides R\&D results produced by academic organisations-and thus highlights not only B-A collaborations, but the significance-in many cases the necessity-of further types of co-operations as well, namely those between innovators, on the one hand, and their suppliers, competitors, users, other business partners, as well as professional associations, on the other. ${ }^{5}$

\subsection{Innovation in mainstream and evolutionary economics: types of knowledge and policy implications}

Mainstream economics ${ }^{6}$ depicts actors as rational agents facing known and calculable risks and driven by the aspiration to make optimal decisions. In contrast, evolutionary economics of innovation posits that uncertainty is an inherent feature of innovation processes and optimisation, therefore, is excluded on theoretical grounds. Further, while the availability of information has been a focal question in mainstream economics for decades, a major lesson of the evolutionary account of innovation is that firms' performance is determined by their accumulated knowledge-both codified and tacit-and skills, as well as learning capabilities. Information can be obtained via normal market transactions, and thus mainstream economics can readily treat information as a special good. ${ }^{7}$ In contrast, knowledge cannot be bought and used instantaneously-and that applies a fortiori to the types of knowledge required for innovation (how to exploit readily available pieces of information in a new way, e.g. by combining information on different subject matters, how to utilise experience and skills accumulated through previous search processes, and how to assemble these various types of knowledge). One must go through a learning process to acquire knowledge and skills, and it is not only time-consuming, but the costs of trial and error need to be incurred as well. Hence, the uncertain, cumulative and path-dependent nature of innovation is reinforced. Cumulativeness, path-dependence and learning lead to heterogeneity both at micro and meso levels (Castellaci 2008; Dosi 1988; Dosi et al. (eds) 1988; Fagerberg et al. (eds) 2005; Hall and Rosenberg (eds) 2010; Malerba 2002; Pavitt 1984; Peneder 2010).

As to policy advice, the fundamental concept in mainstream economics is market failure: unpredictability of R\&D outputs from inputs, inappropriability of full economic benefits of private investment in R\&D and indivisibility in R\&D results lead to 'suboptimal' level of business R\&D efforts. Two types of policy interventions, therefore, are justified: (a) incentives to boost private $R \& D$ expenditures via subsidies and protection of intellectual property rights, and (b) funding for public R\&D activities.

Evolutionary economics of innovation does not focus exclusively on R\&D. This school identifies various types and forms of knowledge, all relevant for innovation. In particular, the importance of tacit knowledge is stressed, besides codified knowledge. Practical knowledge-acquired, developed, revised and transmitted when performing various tasks-is obviously of crucial importance for the innovation process. Hence, scientific knowledge is far from being the only, or most important, type of knowledge required 
for a successful introduction of new products, processes, services or organisational and market innovations. As for the sources of knowledge, R\&D is clearly among the vital ones (both for codified and tacit knowledge). Besides in-house R\&D projects, however, results of other $R \& D$ projects are also widely exploited for innovation process: extramural projects conducted in the same or other sectors, at public or private research establishments, home or abroad. Further, a number of other sources of knowledge are also of significance for innovations, such as design, scaling up, testing, tooling-up, trouble shooting and other engineering activities, as well as ideas from suppliers, users and NGOs (including patient groups), inventors' ideas and practical experiments (Hirsch-Kreinsen et al. (eds) 2005; Klevorick et al. 1995; Lundvall (ed) 1992; Lundvall and Borrás 1999; von Hippel 1988), as well as interactions among engineers, designers, artists and other creative 'geeks'. In general, all sorts of trial and error processes, learning by doing, using, interacting and comparing contribute to knowledge generation. Further, knowledge embodied in advanced materials and other inputs, as well as in equipment and software is also utilised by innovative firms. All rounds of the Community Innovation Survey clearly and consistently show that firms regard a wide variety of sources of information as highly important to innovation. ${ }^{8}$

In brief, policy implications of evolutionary economics can be derived from two closely related claims. First, the success of firms is largely determined by their abilities to exploit all the above types of knowledge, coming from both R\&D efforts and other activities. Second, knowledge generation, diffusion and exploitation takes place in, and is fostered by, networks, clusters and other forms of co-operation and communications. The quality and frequency of these interactions are largely determined by the institutions-the 'rules of the game'-and other properties of a given innovation system, in which they take place. ${ }^{9}$ STI policies, therefore, should aim at strengthening the respective-sectoral, regional or national-innovation system and improving its performance by tackling systemic failures hampering the production, circulation and utilisation of any type of knowledge required for successful innovation (Dodgson et al. 2011; Edquist 2011; Foray (ed) 2009; Freeman 1994; Lundvall and Borrás 1999; OECD 1998; Smith 2000). Concerning B-A collaborations, deliberate policy efforts are needed to promote its various types, serving knowledge-intensive activities of all firms, regardless whether the aim is a radical innovation, an incremental one or 'just' solving an important technical problem.

\section{Main actors engaged in RTDI activities and their co-operation in EU countries}

Business-academia collaborations have been extensively studied in many countries, from many different angles, using various sources and types of information (e.g. patent statistics, Community Innovation Survey (CIS) data, evidence from tailor-made surveys, interviews, or case studies), but usually a given paper relies on a single method and tackles one or two specific research questions. ${ }^{10}$ In contrast, this article addresses both R\&D and innovation collaborations among businesses and academia by considering information from different set of statistics, namely those on i) sources of R\&D funding for universities and PROs, ii) sources of information for innovations, as well as iii) occurrence and 'value' of innovation co-operation by the type of partners. Further, it also relies on interviews to explore motivations and major features of business-academia co-operation in Hungary.

In other words, for pragmatic reasons the unit of analysis is changing when there is a shift in methods: the unit of analysis is a set of EU countries (all member states, except 
Croatia, Cyprus, Luxembourg and Malta) for statistical analyses (this section), and given the time and other resources needed for interviews, it is only Hungary for qualitative analyses (Section 4). Yet, it is believed that this 'mixed level' of analysis can still illustrate the benefits of using multiple methods for mapping B-A collaborations. Indeed, results of qualitative research conducted in other countries are in line with the findings derived from the Hungarian interviews.

\subsection{The principal research performer sectors}

The business sector is the most important research performer at an aggregate level in the EU27 countries both in terms of its share in GERD and employment, followed by the higher education and the government sectors (Table 1). The share of the private non-profit sector is around $1 \%$ by either measure, and thus it is not analysed here.

The number of researchers (counted as full-time equivalent (FTE)) employed by businesses has increased from 500,377 in 2000 to 763,993 by 2012 in the EU27 countries, and thus remained the largest employers of researchers. ${ }^{11}$ This pattern is not repeated at a country level: in 2012, businesses were the largest employers of (FTE) researchers in $12 \mathrm{EU}$ countries, while the higher education sector took the lead in $11 \mathrm{EU}$ countries, and the government sector in a single country. The share of business enterprise researchers in the EU27 total was $46.5 \%$ in 2012 and varied between $15.2 \%$ (LV) and $62.3 \%$ (AT) in the national total at a country level. This ratio was above $50 \%$ in $11 \mathrm{EU}$ countries and under $30 \%$ in 8 ones (Fig. 1). Business R\&D expenditures (BERD) have increased from $€ 111,181.1 \mathrm{~m}$ in 2000 to $€ 145,652.6 \mathrm{~m}$ in 2012 (PPS at 2005 prices), that is, by $31 \%$. The share of GERD performed by the business enterprise sector was $62.4 \%$ in 2012. At a country level, this ratio was ranging between $22.6 \%$ (LV) and $77.2 \%$ (SI) in 2012, with 6 countries above $67 \%, 7$ relatively close to the EU27 average ratio, that is, between 57 and $67 \%, 6$ between 40 and $57 \%$, and another 5 below $40 \%{ }^{12}$ (Fig. 2).

Higher education (HE) organisations were the second largest employers with 412,473 FTE researchers in 2000 at the EU27 level and 660,040 in 2012, that is, $40.2 \%$ of the EU27 total. Again, there is a great variety at a national level: the share of HE FTE researchers in the national total was ranging between $24.9 \%(\mathrm{HU})$ and $66.8 \%(\mathrm{LV})$ in 2012. It was close to the EU27 aggregate figure, i.e. stood between 37 and $43 \%$ in 4

Table 1 R\&D inputs and the weight of R\&D performing sectors, EU27, 2000 and 2012 (\%)

\begin{tabular}{lcr}
\hline & 2000 & 2012 \\
\hline GERD/GDP & 1.85 & 2.08 \\
Share of researchers (FTE) in total employment & 0.54 & 0.77 \\
Business sector & & \\
BERD/GERD & 63.75 & 62.36 \\
Share of business researchers (FTE) & 46.00 & 46.48 \\
Higher education sector & & 23.88 \\
HERD/GERD & 21.18 & 40.16 \\
Share of HE researchers (FTE) & 37.69 & \\
Government sector & & 12.89 \\
GOVERD/GERD & 14.29 & 12.17 \\
Share of government researchers (FTE) & 15.24 & \\
\hline
\end{tabular}

Source: Eurostat and author's calculation based on Eurostat data 


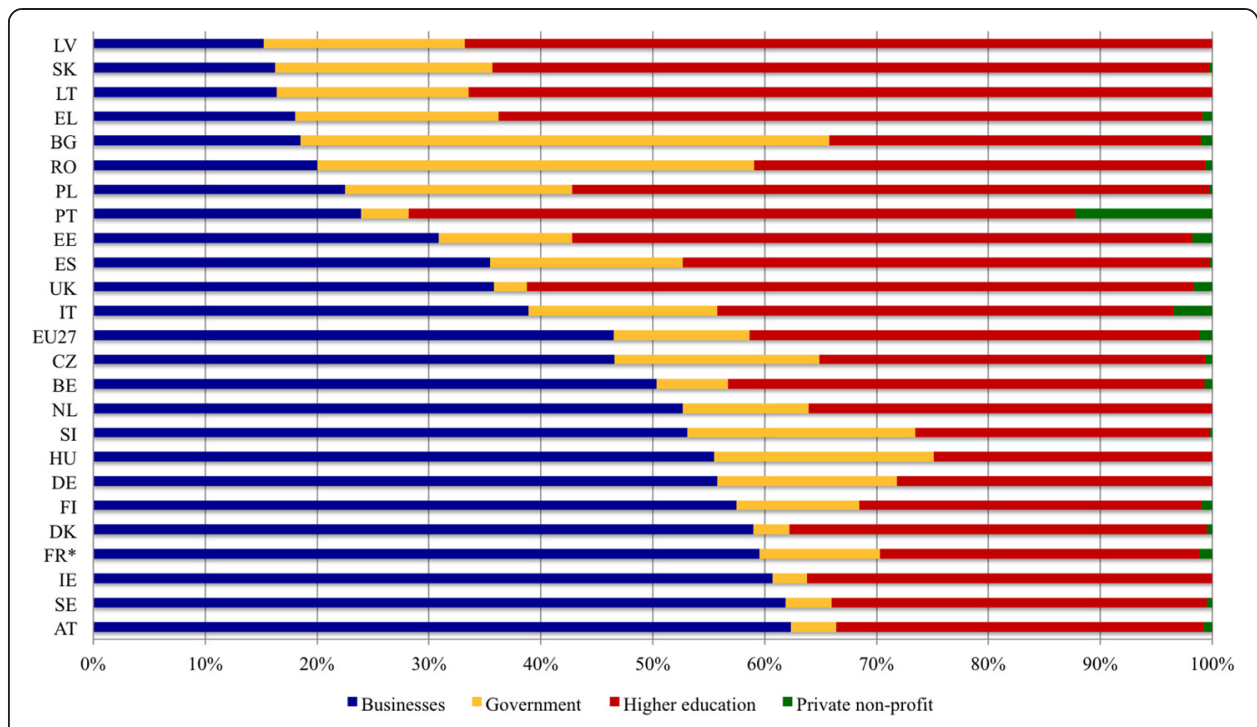

Fig. 1 Share of research performing sectors in employing FTE researchers, EU countries, 2012 (\%)

countries, below $37 \%$ in 11 countries, in the range of $43-60 \%$ in 5 countries, and above $60 \%$ in 4 countries (Fig. 1). The total EU27 R\&D expenditures in the HE sector (HERD) have increased by $51 \%$ in absolute terms: from $€ 36,933.9 \mathrm{~m}$ in 2000 to $€ 55,776.0 \mathrm{~m}$ in 2012 (PPS at 2005 prices). The share of GERD performed by the HE sector is significantly lower: it fluctuated between 21.2 and $23.9 \%$ in 2000-2012 at the aggregate level of $27 \mathrm{EU}$ countries. The HERD/GERD ratio varied between $8.0 \%$ (BG) and $53.7 \%$ (LT) in 2012 at a country level. In 5 countries, it was in the range of 8-21\%, in another 6 close to the EU27 ratio (between 21 and $27 \%$ ), in 11 ones between $27-40 \%$, and in 2 ones above $50 \%$ (Fig. 2).

At an aggregate level the government sector was the No. 3 employer with 166,791 FTE researchers in 2000, and 200,045 in 2012, that is, less than one third of the HE

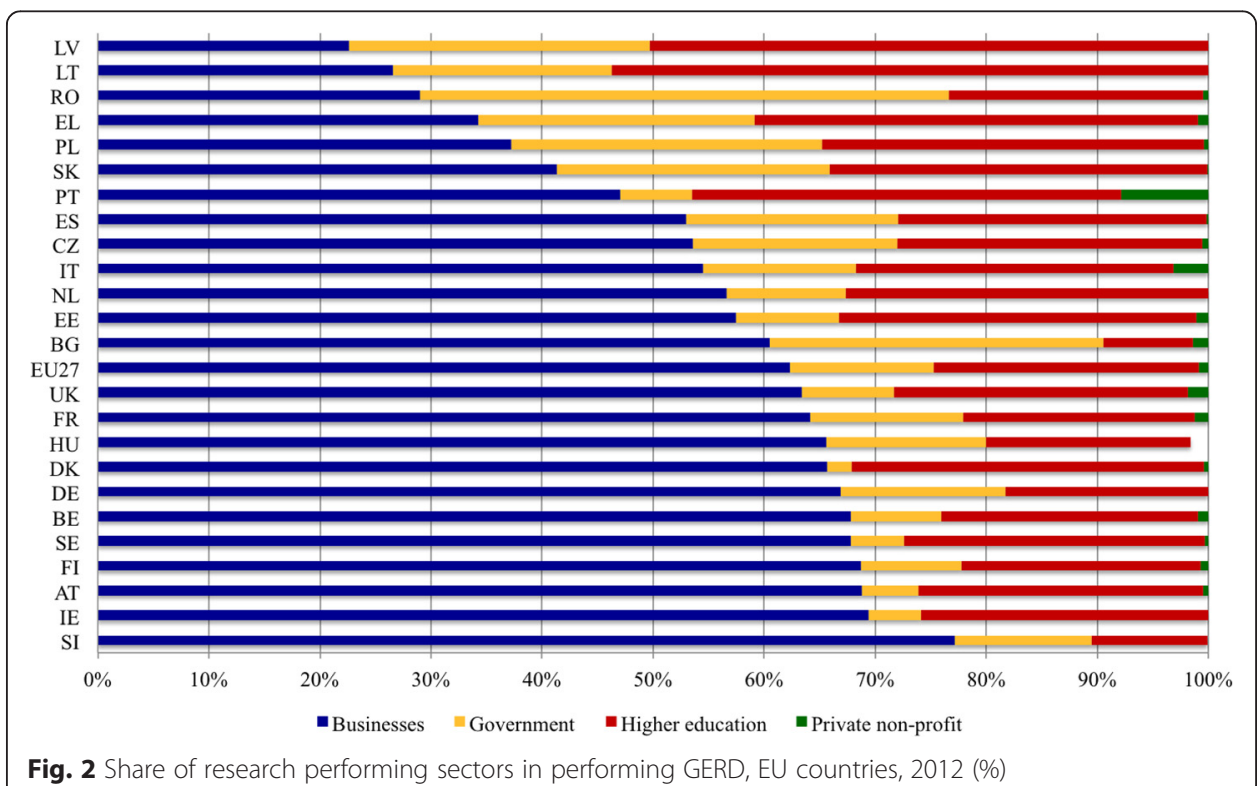

Fig. 2 Share of research performing sectors in performing GERD, EU countries, 2012 (\%) 
figures. The share of this sector was $12.2 \%$ of the EU27 total in 2012, but the variation at the country level is significant in this case, too: the weight of the government sector is ranging between $3.0 \%$ (UK) and $47.3 \%$ (BG). This share is below $7 \%$ in 7 countries, between 11 and $12 \%$ (that is, very close to the EU27 aggregate) in 4 countries, between 16 and $21 \%$ in 11 countries, and above $39 \%$ in 2 countries (Fig. 1). The share of GERD performed by the government sector was in line with its share in employment, that is, $12.9 \%$ in 2012 at the aggregate EU27 level. At the country level, this share varied from $2.2 \%$ (DK) to $47.6 \%(\mathrm{RO})$ in 2012: it was below $10 \%$ in 10 countries, between 10 and $15 \%$ (i.e. close to the EU27 ratio) in 6 countries, between 15 and $30 \%$ in 8 countries, and close to $50 \%$ in RO (Fig. 2).

As a 'broad brush' observation, the more advanced an economy is, the higher the weight of businesses in employing researchers and performing R\&D (Figs. 1 and 2). Of course, more detailed analyses would be needed to draw sound theoretical and policy conclusions, taking into account the context of each country, e.g. historical legacies, organisational and institutional factors, as well as recent sweeping changes in the case of the so-called new EU member states. As for the former, the UK clearly shows that context does matter: the share of researchers employed by businesses is lower than expected (35.8\% in 2012), significantly 'outweighed' by the higher education sector (59.6\%), but the 'anticipated' ratio can be observed as for the share of these two sectors in performing R\&D: 63.4 vs. $26.5 \%$.

As for the latter, businesses in Hungary and Slovenia have achieved a high share in employing researchers, due to a fairly radical restructuring: in Hungary from $27.1 \%$ in 2000 to 55.5 in 2012, and from 31.8 to $53.1 \%$ in Slovenia. These changes were less profound in the Czech Republic: 39.9 vs. $46.6 \%$. As for performing R\&D, the most noteworthy changes occurred in Bulgaria, where the share of businesses increased from $21.4 \%$ in 2000 to $60.5 \%$ in 2012; and in Estonia: from 22.5 to $57.4 \%$. Again, a detailed analysis would be required to identify if genuine structural shifts or reclassification of research performing organisations have caused these drastic changes. Yet, even this short overview is sufficient to indicate that country differences do matter even when one considers a group of countries characterised by broadly similar features.

\subsection{The weight of business resources in funding R\&D activities}

BERD is mainly financed by businesses' own resources: this share was fluctuating in a narrow range of $81.3-83.2 \%$ in 2000-2011. From a different angle, the bulk of business $R \& D$ funds is devoted to business R\&D activities: $94.8-95.7 \%$ in the same period. It is worth stressing, though, that in some countries businesses fund research activities both at HE institutes and in the government sector (publicly financed R\&D institutes, or PROs) to a noteworthy extent.

While at the EU27 level 6.3-6.8 \% of HERD was financed by businesses in 2000-2012, at a country level, one can find much more variation both in terms of the ratio of business sources and dynamics (Fig. 3). The share of business sources in funding HERD was around or above $10 \%$ in 6 countries, around $7-8 \%$ in 4 countries, $3-5 \%$ in 8 countries and less than $3 \%$ in 6 ones in 2012. In some countries, this share decreased significantly, e.g. from $30.8 \%$ in 2000 to $16.0 \%$ in 2012 (BG), or from $27.1 \%$ to 5.4 (LV). Overall, this share grew in 10 countries by 2012, among these by around 4 percentage points in 


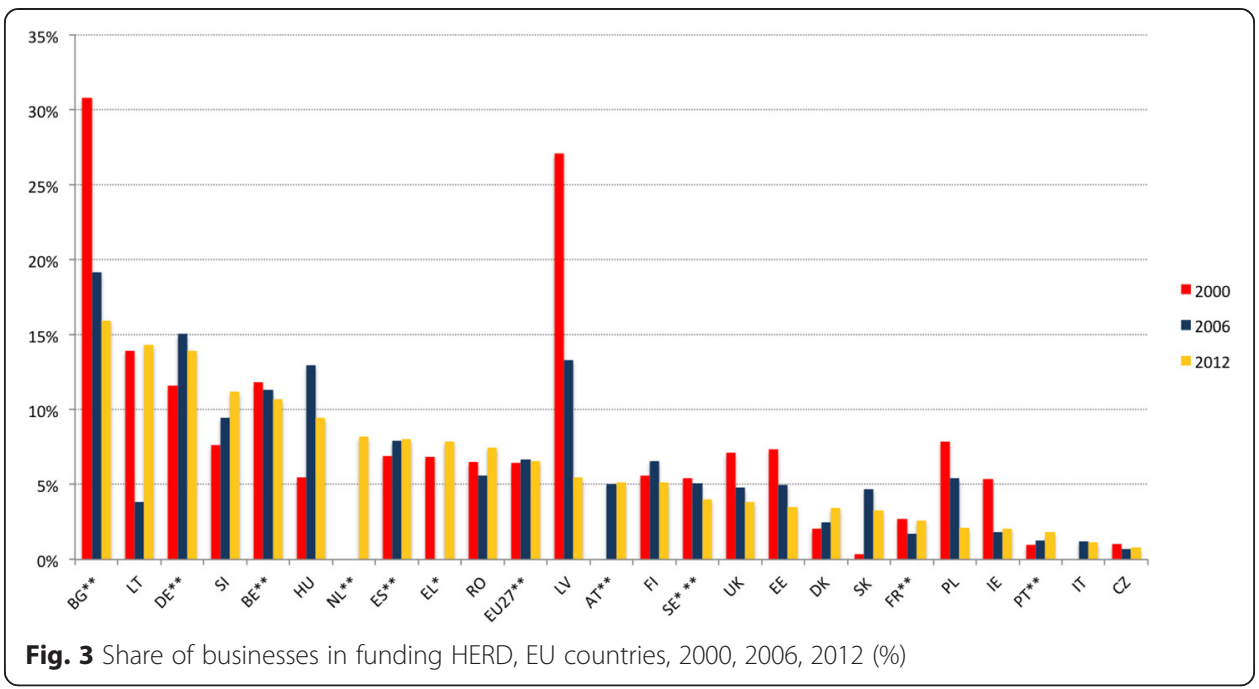

Hungary and Slovenia, and by 2.3 percentage points in Germany from an already high level, and declined in 11 countries (missing data for 3 countries).

The share of business sources in funding HERD is higher than the aggregate EU27 figure in 10 countries, of which 5 are new member states and 1 is a less developed Southern European country. The relatively high ratio of business funding in these countries might be attributed to the low amount of HERD in absolute terms: a few projects commissioned by firms, with relatively low budgets by international standards, can lead to a high weight of business funding in HERD.

The share of business sources in funding Government Intramural Expenditure on R\&D (GOVERD) was 5.7-8.9 \% at an aggregate EU27 level in 2000-2012. As for the member states, this ratio was in the range of $1.1 \%$ (PT [2011]) and $17.3 \%$ (RO) in 2012. It was above $10 \%$ in 8 countries, $7-9 \%$ in 4 countries, $4-6 \%$ in 8 countries and 1-3 \% in 4 ones in 2012 (or 2011) (Fig. 4). This ratio increased in 9 countries (by 7 percentage points in DE, $3-4$ percentage points in 3 countries, around 2 percentage points

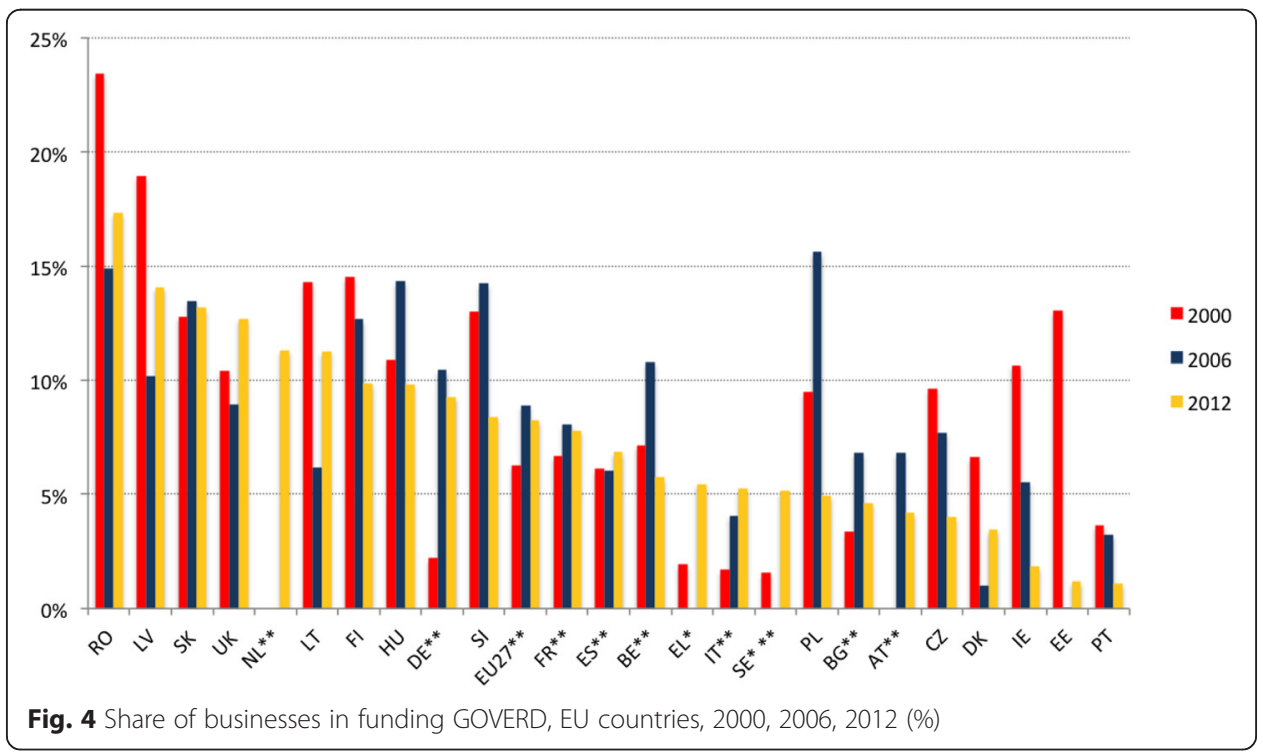


in 2 countries, around 1 percentage point in 3 countries and just 0.4 point in 1 country) and decreased in 13 cases (by 6-12 percentage points in 4 countries, by 3-5 points in another 4 and by $1-2.5$ points in the remaining 3 countries).

The share of GOVERD financed by businesses is higher in 10 member states than the EU27 figure, and 6 of these are new members. The low volume of GOVERD in these countries, most likely, is an important factor in explaining the high value of this ratio.

\subsection{Information sources for innovation-as assessed by firms}

The quality of co-operation among the NIS players can be characterised by firms' assessments as to the importance of sources of information for their innovation activities. In all countries participating in CIS2008 ${ }^{13}$ and CIS2010, the largest share of firms regards their own enterprise or enterprise group as a highly important source of information for innovation, and other firms-suppliers, customers, competitors and commercial labs-are also highly appreciated by a large part of firms. Thus Fig. 5 only presents these businesstype sources of information. The other sources-which can be called 'scientific' ones in a somewhat simplified way-are depicted on Fig. 6. These are 'highly important sources of information' for a significantly lower share of innovative firms. In most countries conferences, trade fairs and exhibitions ranked first in this group, scientific journals and trade/technical publications came second, followed by universities and public research institutes. Universities were among the top 3 in seven countries in 2008-2010: they came second in Estonia, Finland and Hungary, while third in Belgium, the Czech Republic, Poland and Spain. PROs were ranked No. 2 in Spain, while in all other countries No. 5, except Poland (No. 3) and the Czech Republic (No. 4).

\subsection{Types of partners in innovation co-operation and firms' assessment}

Data on innovation co-operation partners are only available at the EU27 level for 2002-2004 and 2008-2010. In both periods, $25.5 \%$ of innovative enterprises reported being 'engaged in any type of co-operation'. Overall, a larger share of innovative firms

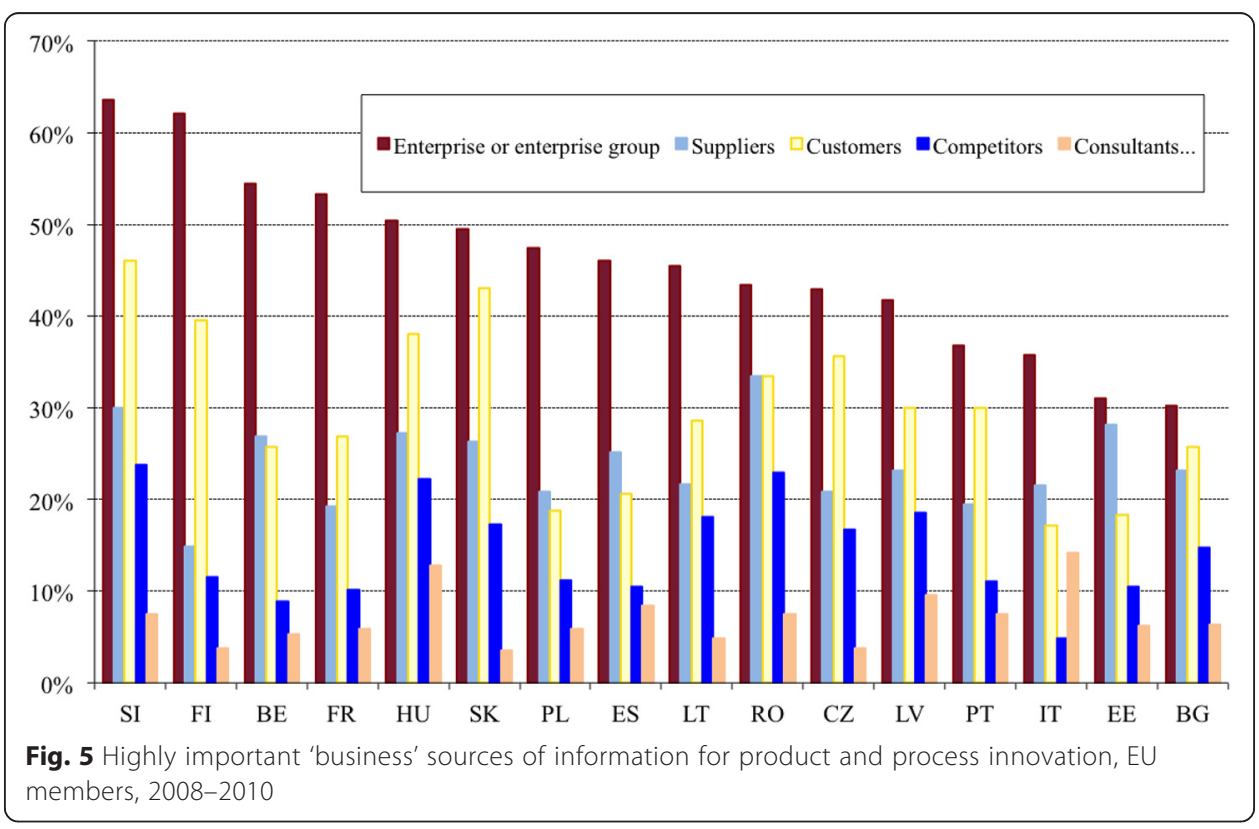




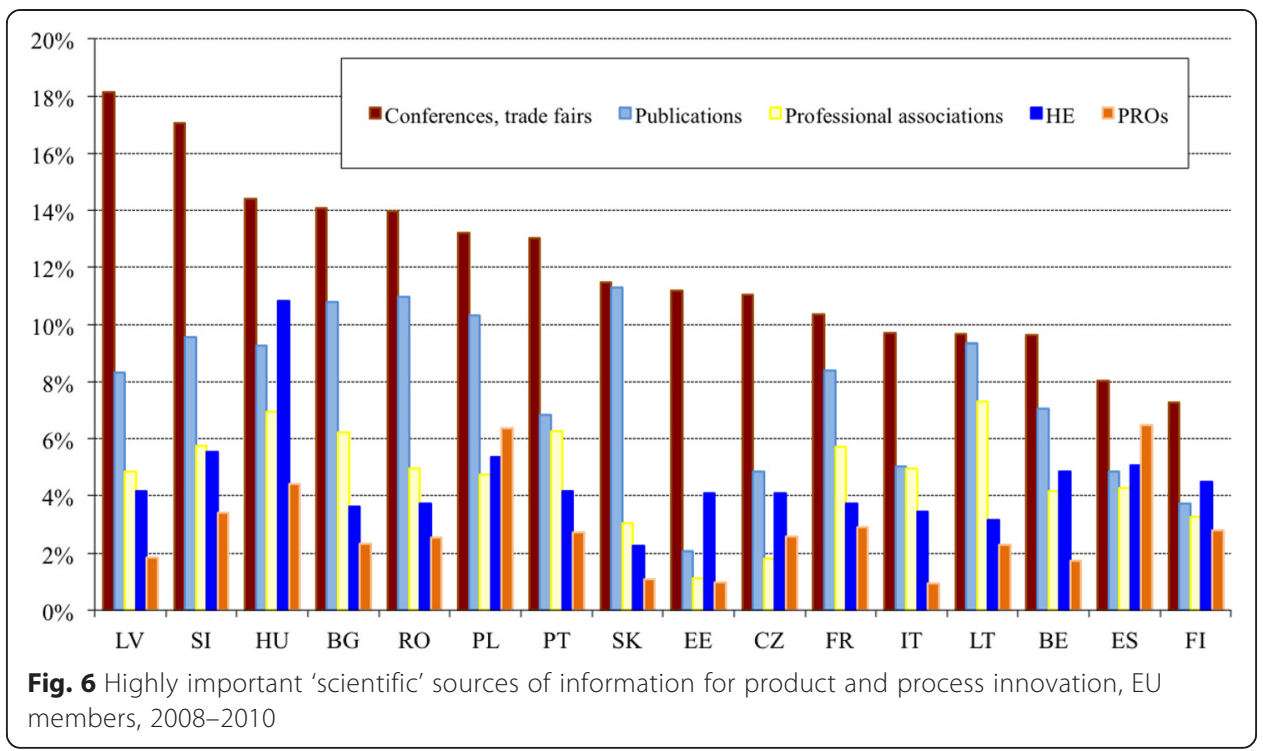

have co-operated with business partners (other enterprises in their group, suppliers, clients, competitors and commercial labs) than with higher education institutes (HEIs) or publicly financed research organisations (PROs) (Table 2). Suppliers of equipment, materials, components or software were mentioned by the highest share of innovative firms as co-operation partners in both periods (16.5 and $15.2 \%$, respectively). HEIs have become partners for a higher share of firms by 2008-2010 (8.8 vs. $10.8 \%$ ), and thus 'overtaken' three types of business partners (out of five), including other enterprises within the enterprise group. PROs have remained the least frequently mentioned co-operation partners, but 2008-2010 saw a slight increase.

There are significant differences among EU members in this respect, too, and thus Fig. 7 presents country-level data. Almost in all countries the highest share of innovative firms report co-operation with suppliers, with the exception of Finland and the UK (where customers are the top co-operation partners), and Germany (HEIs). It is noteworthy that $23-35 \%$ of innovative firms co-operate with suppliers in 15 countries, and $16 \%$ of firms do so in another 2 countries, while the aggregate EU27 figure is $15.2 \%$. Similarly, 21-30 \% of innovative firms co-operate with clients or customers in 14 countries, and 13-15\% of firms do so in another 3 countries, while the aggregate EU27 figure is $12.6 \%$. As for competitors or other enterprises in the sector, $8-31 \%$ of innovative firms in 14 countries co-operate

Table 2 Share of innovative enterprises indicating co-operation with specified partners, EU27, 2002-2004 and 2008-2010 (percentage of all innovative enterprises)

\begin{tabular}{lrr}
\hline & 2002-2004 & 2008-2010 \\
\hline Other enterprises within the enterprise group & 9.5 & 9.3 \\
Suppliers of equipment, materials, components or software & 16.5 & 15.2 \\
Clients or customers & 13.9 & 12.6 \\
Competitors or other enterprises in sector & 8.3 & 6.7 \\
Consultants, commercial labs, private R\&D organisations & 8.9 & 9.7 \\
Higher education organisations & 8.8 & 10.8 \\
Government or public research institutes & 5.7 & 6.1 \\
\hline
\end{tabular}




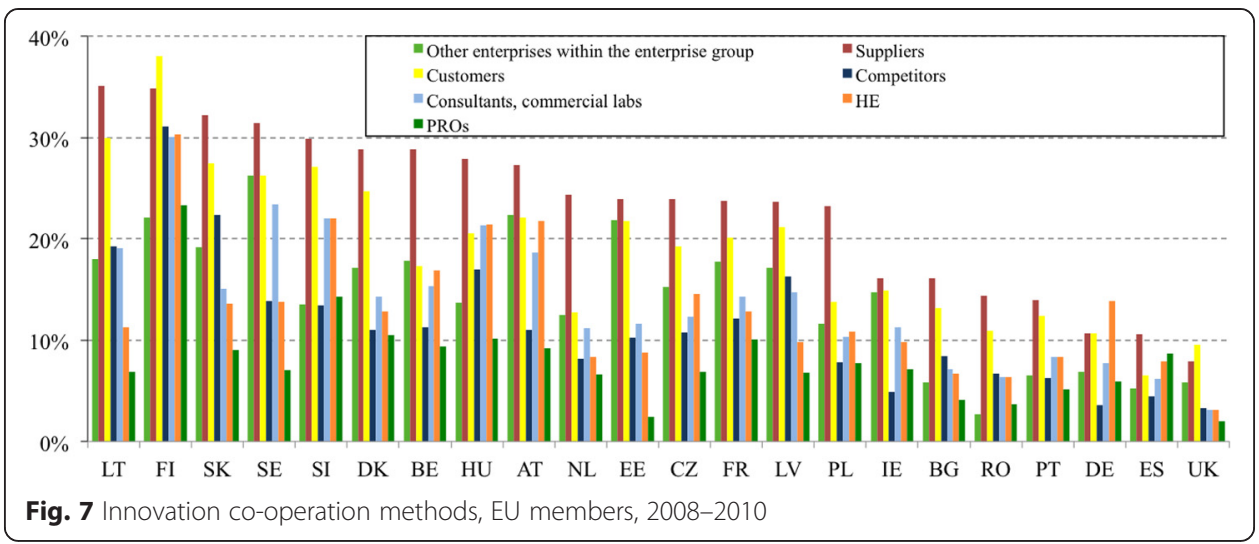

with them, as opposed to the ratio of $6.7 \%$ for the EU27 countries. Finally, 12-26\% of innovative firms in 16 countries co-operate with other enterprises within the enterprise group, which is well above the EU27 figure (9.3\%). In short, innovation co-operation with 'business' partners are much more widespread in a large number of countries than suggested by the aggregate EU27 data.

It is also interesting to note that there is no clear division between the more and the less advanced member states (or the ones belonging to various groups defined using the so-called Summary Innovation Index). For example, Lithuania, Slovakia and Slovenia are next to Finland, Sweden and Denmark on Fig. 7, while Bulgaria and Romania are in the same group as Germany, Spain and the UK. ${ }^{14}$ In other words, the higher occurrence of innovation co-operation does not necessarily mean a better innovation-and ultimately economic-performance. Clearly, there are many other factors influencing innovation performance-and much more determining economic one. As for the former, the quality of co-operation is among those factors. Thus, when analysing B-A co-operation, it is also important to note which co-operation method is the most valuable one for firms.

In most EU countries, co-operation with suppliers, customers and other enterprises within the enterprise group is mentioned by a relatively large portion of firms as the most valuable method (Fig. 8). Yet, in eight countries, co-operation with higher education institutes are among the top three methods: HEIs were ranked first in Germany (6.6 \% of the innovative firms mentioned this method as the most valuable for innovation, and only $4.2 \%$ perceived suppliers as the most valuable innovation cooperation partners), second in Hungary (8.5\%), while third in Austria (8.0\%), Belgium

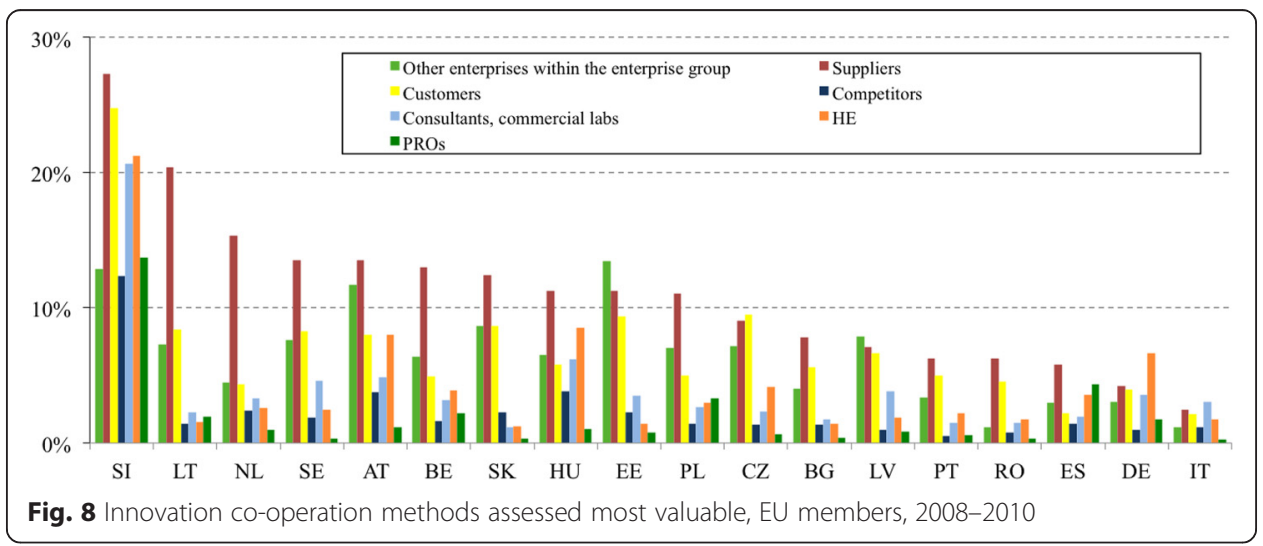


(3.9\%), the Czech Republic (4.2\%), Romania (1.7\%), Slovenia (21.3\%) and Spain $(3.6 \%) .{ }^{15}$ PROs are assessed far less favourably: besides Spain, where they are ranked No. 2 (4.3\%), nowhere else they are among the top three.

Finally, Figs. 9 and 10 zoom into innovation co-operation with HEIs and PROs, respectively. Finland is way ahead of other countries in both cases, and although there are no data as to how Finnish firms assess the various types of innovation co-operation partners, it is highly likely that they find co-operation with both HEIs and PROs useful, otherwise they would be engaged in these B-A collaborations to a lesser extent. It is also worth noting that a high share of innovative Finnish firms tends to co-operate: Finland is the only country where any of the seven types of innovation co-operation partners is mentioned at least by $22 \%$ of innovative firms (and on top of that, five types are mentioned by around or well above $30 \%$ ) (Fig. 7).

\section{Business-academia collaborations in Hungary}

\subsection{Main characteristics}

It has been a recurring theme of various reports and policy documents that the intensity, frequency and quality of B-A co-operation in Hungary have been significantly below the desired level (Arnold et al. 2007; Borsi 2005; Havas 2004, 2009, 2011; Havas and Nyiri (eds) 2007; Inzelt 2004; Inzelt et al. 2009; OECD 2008). The SME development strategy of the Ministry for Economy and Transport has stressed that knowledge diffusion between publicly financed research institutes and businesses has been insufficient; directors of PROs have not considered businesses' interests when defining research themes or assessing researchers' performance; and researchers have hardly moved between PROs and businesses (GKM 2008, p. 34).

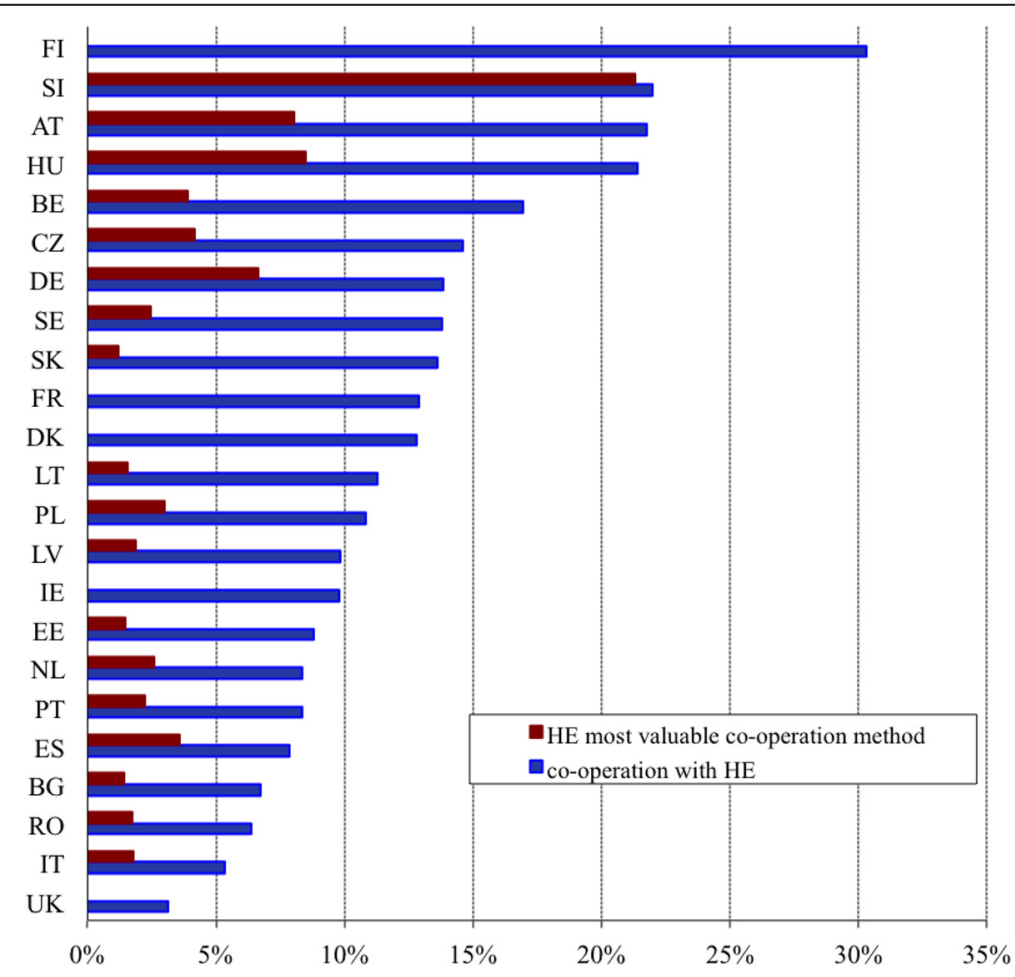

Fig. 9 Innovation co-operation with higher education institutes, EU members, 2008-2010 


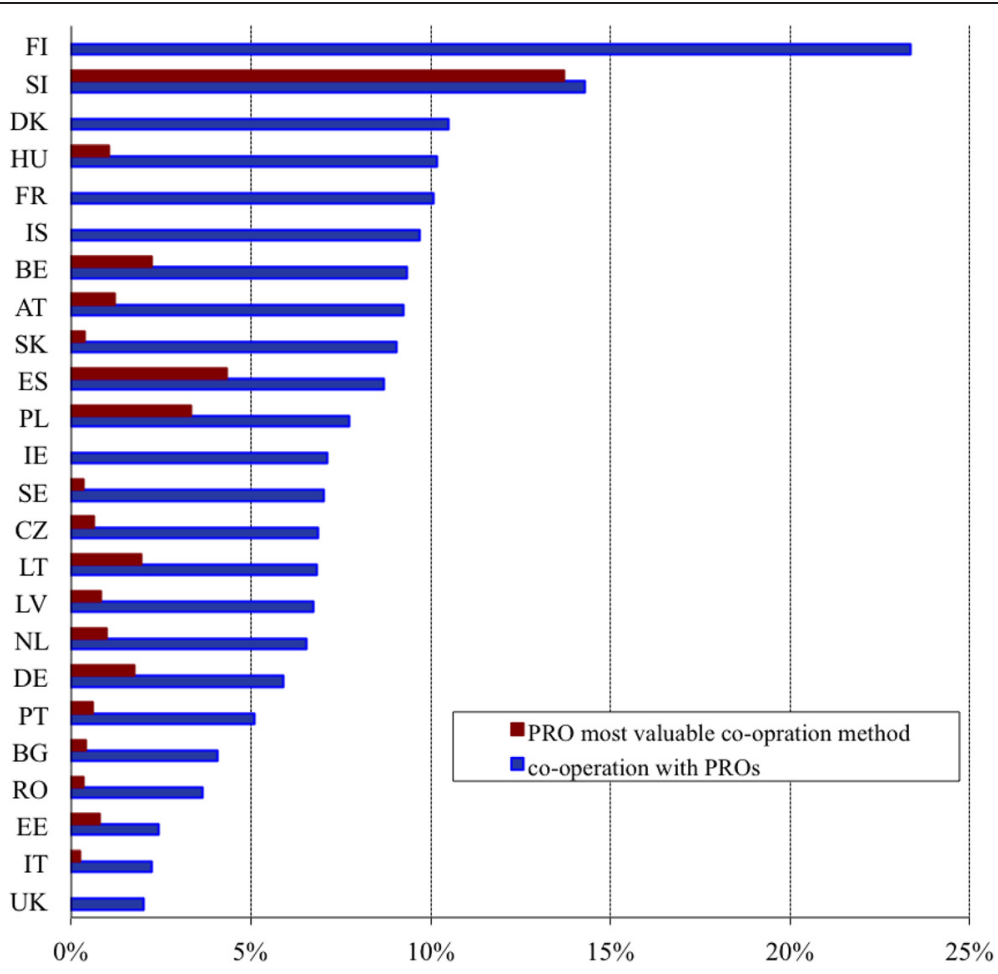

Fig. 10 Innovation co-operation with PROs, EU members, 2008-2010

Thus, several Hungarian STI policy measures have been devised with the aim of promoting B-A co-operation, either by making this type of collaboration compulsory, or giving priority to joint project proposals of firms and universities or PROs. ${ }^{16}$ These measures seem to have had some positive impacts: various types of statistical data as well as evaluation reports indicate that the frequency of B-A collaboration has increased to a noteworthy extent since 2000. While only $4-5 \%$ of the Hungarian HERD had been financed by firms in 2000-2001, this ratio jumped to $11-13 \%$ in $2002-2006$, further increased in 2007-2010, reaching its peak at $15.5 \%$ in 2009, and then dropped to 10-11\% in 2011-2013. As for the composition of GOVERD, the share of business funding started at a high level of 11-13\% in 2000-2001, halved in 2002-2004, exceeded $10 \%$ again in 2005 and was in the range of $9.7-14.3 \%$ in 2007-2013 (Table 3).

Recalling the data presented in Section 3.2, these Hungarian ratios are fairly high compared to the aggregate EU27 figures. As already mentioned with regard to other new EU members, this high ratio of business funding might stem from a few projects commissioned by firms, with a relatively small budget by international standards, given the low level of the Hungarian HERD and GOVERD in absolute terms (€97-243 m, and $€ 106-248 \mathrm{~m}$ a year in 2001-2013, respectively, at current prices).

Table 3 The share of businesses in funding HERD (A) and GOVERD (B) in Hungary, 2000-2013 (\%)

\begin{tabular}{rrrrrrrrrrrrrrr}
\hline & 2000 & 2001 & 2002 & 2003 & 2004 & 2005 & 2006 & 2007 & 2008 & 2009 & 2010 & 2011 & 2012 & 2013 \\
\hline A & 5.5 & 4.4 & 11.8 & 10.6 & 12.9 & 11.8 & 13.0 & 13.7 & 14.7 & 15.5 & 13.6 & 11.3 & 9.5 & 8.6 \\
B & 10.9 & 13.1 & 6.4 & 5.7 & 7.2 & 10.3 & 14.3 & 12.3 & 13.3 & 12.6 & 12.7 & 11.5 & 9.8 & 9.7 \\
\hline \multicolumn{7}{l}{ Source: author's calculation based on CSO data }
\end{tabular}

Source: author's calculation based on CSO data 
Hungarian universities are the second most important information sources for innovation when the so-called 'scientific' sources are considered, moreover, by far with the highest appreciation compared to their counterparts in the other EU countries. As for PROs, they are the least important information sources, just as in most other EU members (Fig. 6).

A significantly higher share of innovative Hungarian firms indicate co-operation with universities and PROs than the EU27 average: 21.4 vs. $10.8 \%$, and 10.2 vs. $6.1 \%{ }^{17}$ (Table 2 and Fig. 7). At a country-level comparison, concerning the frequency of innovation co-operation between businesses and higher education institutes, Hungary was ranked four in 2008-2010-up from her fifth position in 2006-2008and universities had a higher appreciation only by Slovene firms $(21.2 \%$ of them perceived this one as the most valuable co-operation method), that is, Hungarian universities are ranked second in this respect (Fig. 9). Taking the frequency of innovation co-operation between business and PROs, Hungary was ranked sixth (up her sixteenth position in 2006-2008). Again, Slovene firms gave the highest appreciation to PROs (Fig. 10).

Finally, two evaluation reports touch upon B-A collaboration in Hungary. The first one considers the impacts of a single measure, called KKK, Co-operative Research Centres, and concludes that B-A co-operation has contributed to improved competitiveness of firms and also led to the set-up of several spin-off firms (Netwin and Laser Consult 2005). The second one, evaluating the use of the Research and Technological Innovation Fund-the most important domestic fund to support RTDI activities-in 2004-2009 has also asserted that due to various schemes, financed by the Fund, B-A co-operation has strengthened (Ernst \& Young and GKI 2010, pp. 7, 89-90).

\subsection{Firms' motivations for, and types of, R\&D and innovation co-operation}

Interviews conducted in four sectors-automotive industry, pharmaceuticals, telecom equipment manufacturing and software development ${ }^{18}$-have confirmed that companies and public R\&D units (HEIs and PROs) are driven by fundamentally different incentives and goals to be involved in $R \& D$ and innovation activities. Hence, there are inherent hindrances to B-A collaboration. In brief, companies are interested in a relatively wide array of R\&D activities (from day-to-day problem solving to long-term strategic research, some of which may require producing advanced scientific and technological knowledge, or even path-breaking new theoretical results), but those should lead to business results (e.g. enhanced productivity, larger market shares, entry to new markets, increased profits). Projects are regularly monitored and assessed, and when necessary, a given project could be substantially reshaped (e.g. in terms of the number of participants, R\&D methods applied, budget), or even stopped. Thus, tight project management (meeting deadlines and 'respecting' budget constraints) and keeping commercially sensible information secret are of vital importance. In contrast, researchers working for universities and PROs are not simply interested, but even forced to disclose their results as quickly and as widely as possible, given the evaluation criteria applied in the academic world. Further, they are usually less accustomed to tight project management, but noticeable changes have occurred in recent years, due to tighter control exercised by both the domestic and foreign funding agencies.

These systemic hindrances to B-A collaborations-different goals and incentives for academic researchers and businesses-are not a unique feature of the Hungarian innovation 
system. Several 'profound differences in the "scientific" and "industrial" cultures'-fairly similar ones to those observed in Hungary-have been highlighted in a presentation by the General Secretary of the European Council of Academies of Applied Sciences, Technologies and Engineering (Lukasik 2013).

Based on the interviews conducted with Hungarian firms, at least three fundamentally different types of business-academia collaboration can be identified. ${ }^{19}$ No doubt, other types of co-operations might also be found, and a more detailed, more refined classification could also be devised. This tentative taxonomy considers two major aspects: whether there is any ownership link between the partners, and the main objectives of co-operation.

1) Co-operation between $R \& D$ intensive spin-off companies and their founding university or PRO

Research-intensive spin-off firms naturally co-operate closely with those research units where their co-founders used to work (or still keep a part-time position). In spite of strong personal contacts, certain frictions might hinder co-operation in these cases, too, given the rigid structures and slow, cumbersome decision-making processes at HEIs and PROs. These tensions can be further aggravated when the founding university/PRO is constrained either by regulations or its own internal rules and norms in considering the business interests of the spin-off firms and in finding a common ground between academic and business cultures. The goals and nature of RTDI co-operation between these types of partners are driven by the business opportunities of the spin-off firm (what research capacities of the university/PRO -including human resources-can be rented/hired for joint projects).

2) Co-operation aimed at solving short-term, relatively simple technical problems Most companies, even those using fairly basic production technologies, regularly face technical problems: a new material or component/sub-system should be used, given an incremental innovation, or a new supplier; production costs should be reduced, products and/or production processes/methods should be improved at the request of a client, and thus new equipment should be added to the existing production lines, etc. Large companies tend to rely on their internal resources to perform these tasks. Small- and medium-sized firms, however, are likely to seek external assistance, usually universities or colleges located nearby. There is an even stronger incentive to co-operate when public support is available to solve technical problems in a collaborative way.

3) Strategic, long-term $R \& D$ and innovation co-operation

Larger firms, pursuing to maintain their competitive edge, are more interested in co-operating with universities and PROs on strategic, long-term R\&D projects to explore new technological opportunities, or breaking new grounds. In these cases, firms can benefit from collaborating with academic researchers who possess advanced science and technology (S\&T) knowledge, and are also embedded in international networks: firms thus can gain access to an extensive pool of knowledge. By sharing tasks and knowledge, firms can reduce the costs of research and better cope with scientific uncertainties. Moreover, several domestic and EU schemes promote this type of co-operation, further reducing costs.

As part of these long-term, strategic collaborations, firms also support $\mathrm{PhD}$ courses financially and/or offer PhD students relevant themes (projects) for their thesis. 
Besides the S\&T results achieved by these projects, a major advantage for firms is that they can collect direct experience as to how these students work-how they solve problems, communicate and co-operate with team members, take the pressures from deadlines, inevitable failures, tensions with colleagues, etc.- and thus can make a better informed decision as to whom to employ, as opposed to the case when they can only rely on a few documents and interviews.

A broader form of co-operation is supporting tertiary education by donating modern equipment to universities. In that way, firms can make sure that the next generation of engineers and scientists would be familiar, e.g. with up-to-date measurement techniques and experienced in using other instruments/techniques, which might not be available at universities without these co-operations.

This type of co-operation-and thus at least some of the elements mentioned above - can be of relevance for those small- and medium-sized companies, too, for which gaining access to advanced S\&T knowledge and new talents is of crucial importance.

This tentative taxonomy can-and should-be developed into a more detailed and better-substantiated typology. Depending on the objectives of further analyses, the following aspects can be used when refining it: the objectives, organisational form and duration of co-operation; types of participants (domestic vs. foreign universities and firms); major characteristics of the business participants (size, ownership, specific sectoral/technological/strategic features, etc.)

Even this tentative taxonomy is sufficient to stress that heterogeneous firms are faced with different needs, posses distinctive capabilities, set specific goals and thus pursue different RTDI strategies. Hence, different forms and types of B-A co-operations can be observed, with specific goals and activities. STI policies, however, tend to neglect this diversity, and not only in Hungary. For example, major EU policy documents tend to mention only type 3) B-A collaboration, while type 2) ones seem to be equally relevant in improving firms' innovation performance and hence competitiveness (see, e.g. EC 2013a, 2013b).

\section{Conclusions, methodological and policy implications}

Mapping, understanding and promoting co-operation among the actors of innovation systems is at the forefront of interest of analysts and policy-makers in many countries. Evolutionary economics of innovation stresses that different types of knowledge, skills and experience are required for successful innovation processes, and these elements are rarely possessed by single entities; rather, these are distributed among various actors. Hence, their co-operation is vital to integrate these elements to exploit them for economic and social ends. One of the major conclusions of this article is that mapping B-A collaborations by using multiple methods and multiple sources of information can significantly improve the reliability and richness of our understanding and can offer insights on the dynamics and qualitative features (e.g. motivations, incentives, strategic considerations) of these cooperation processes.

As for the sources of information for innovations, universities and PROs are less important for innovative firms in the EU countries than their own enterprise or other firms in their 
group, customers, suppliers, competitors and/or other firms in the same sector. As to innovation co-operation, almost in all countries the highest share of innovative firms reports co-operation with suppliers and the other business partners (clients, competitors or other enterprises in sector, other enterprises within the enterprise group) are also significantly more frequently mentioned co-operation partners than academic organisations. In eight countries, though, HEIs are among the top three co-operation partners when firms identify the most valuable method of co-operation. In contrast, PROs have that standing in a single country only. Yet, further work would be required to establish if sectors (and various types of firms in the same sector) differ in their intensity and patterns of B-A co-operations.

Given the diversity of the types of knowledge required for successful innovation process, patent statistics can only reflect one aspect of one type of B-A collaboration in certain sectors (where the propensity to patent is relatively high). Yet, there are other aspects of B-A collaborations even in those cases when S\&T knowledge is a main type of knowledge to be co-produced-let alone those cases where the main objective of a B-A co-operation is to adapt existing knowledge to a new context or problem, or address a relatively simple technological or business issue. These latter types are likely to be of a huge economic importance even in advanced economies (let alone less developed ones), given the weight of the so-called low- and medium-tech sectors in generating employment and producing output. More generally, relying merely on quantitative analyses, one cannot observe the various types of B-A co-operation.

Findings have also confirmed that (i) motivations, incentives for, and norms of, conducting RTDI activities diametrically differ in business and academia; and (ii) different types of firms have different needs. Thus, more refined policy measures are to be devised to promote B-A collaboration more effectively, better tuned to the needs of the actors, based on a relevant taxonomy of RTDI collaborations.

Further, evaluation criteria for academics should also be revised to remove some major obstacles, currently blocking more successful B-A co-operation. Obviously, it would require sound analyses of a given higher education system, and then a thorough decision-preparatory process, involving major stakeholders; otherwise, a fierce opposition is likely to arise from academics, given strong traditions at universities and PROs. Academic entrepreneurial orientation is at an early stage in many countries, with traditional and newly emerging academic roles yet to be fully understood and exploited by HE and PRO managers (Etzkowitz et al. 2000).

Interviews also suggest that in some cases collaborative projects had already been decided; i.e. an available support scheme has not oriented the RTDI activities of a given firm. Moreover, several B-A collaboration projects would have been conducted without public support, too. In other words, additionality in the narrow sense has been fairly low. More detailed case studies would be needed to establish if additionality in the broader sense-the so-called behavioural additionality-can be observed (Lipsey and Carlaw 1998; OECD 2006).

Consultancy firms specialising in identifying opportunities to obtain public support and drafting project proposals have played a major role in several Hungarian cases. Without them a number of firms would have not applied for public support. A larger sample would be needed to draw firm policy conclusions. So far, only diametrically opposite interpretations can be put forward as hypotheses, derived from the observed cases. A) These consultancy firms play a useful role in 're-wiring' and revitalising the 
Hungarian NIS: they disseminate vital information and build contacts among the interested players more effectively than the responsible government agencies and other public (non-profit) organisations charged with these tasks. Or, B) these consultancy firms pursue a special rent-seeking strategy, and appropriate some $10-15 \%$ of public funds earmarked for these types of innovation co-operation. ${ }^{20}$

Both the methodological and policy implications seem to be valid beyond the cases considered, in spite of the fact that interviews have only been conducted with firms in a single country. Indeed, the Hungarian national innovation system has certain specific features-but that applies to every other country. In other words, no policy analyst or policy-maker should hope that a 'representative' case can be identified, and then 'best practice' policy tools can be easily and successfully 'transferred' from that country to a different one. What can be learnt from the Hungarian case is that there are significant differences (i) between business and academic partners in a B-A collaboration (in terms of their motivations, objectives, norms and values), as well as (ii) among firms (in their needs, internal resources, routines, competences and access to external assistance and information). Therefore, the research design to analyse B-A collaborations (identify their types and impacts) needs always to be tailored to the innovation system in question, as well as the concomitant policy recommendations (what type of policy support is missing, what should be strengthened, redirected or even stopped).

More generally, the analysis of B-A collaborations presented above also suggests that the role and possible impacts of STI policies in supporting innovation process-perceived in radically different ways, e.g. in China, other Asian countries, the US, the European Union and in emerging economies-are a prime candidate for a broader comparative analysis.

\section{Endnotes}

${ }^{1}$ Mainstream economics is constantly evolving, driven by its own 'internal' dynamics as well as by integrating new notions, research questions and methods from various schools of economics. Its major features cannot, therefore, be precisely defined once and for all.

${ }^{2}$ It is impossible to give a comprehensive and balanced overview of this huge literature. Only a few groundbreaking pieces, handbooks or other synthesis papers can be highlighted here in a somewhat arbitrary way, excluding the so-called endogenous (or new) growth theory: Baumol 2002; Baumol et al. 2007; Dodgson and Rothwell (eds) 1994; Dosi 1988; Dosi et al. (eds) 1988; Edquist (ed) 1997; Ergas 1986, 1987; Fagerberg et al. (eds) 2005; Fagerberg et al. 2012; Freeman and Soete 1997; Hall and Rosenberg (eds) 2010; Klevorick et al. 1995; Lundvall (ed) 1992; Lundvall and Borrás 1999; Martin 2012; Mowery and Nelson 1999; Nelson (ed) 1993; Nelson 1995; Nelson and Winter 1982; OECD 1992, 1998; Pavitt 1999; Smith 2000; Von Tunzelmann 1995.

${ }^{3}$ Other important research programmes have also emerged, most importantly the various schools of science and technology studies (for a thorough historical overview see, e. g. Martin 2012), but that literature is not explored here.

${ }^{4}$ Just to indicate the extent and the long-lasting impacts of this debate, a recent overview by Di Stefano et al. (2012) relies on not fewer than one hundred papers.

${ }^{5}$ This brief account could only list the most influential models. Balconi et al. (2010), Caraça et al. (2009), Dodgson and Rothwell (eds) (1994) and Godin (2006) offer detailed discussions on their emergence, properties and use for analytical and policy-making purposes. 
${ }^{6}$ The so-called new or endogenous growth theory is not discussed here separately because its major assumptions on knowledge are very similar to those of mainstream economics (Lazonick 2013; Smith 2000). Knowledge in new growth models is reduced to codified scientific knowledge, in sharp contrast to the much richer understanding of knowledge in evolutionary economics of innovation.

${ }^{7}$ Various forms of learning are now studied in mainstream economics, too, e.g. learning by doing and exporting.

${ }^{8}$ See, e.g. EC 2004, Tables 1, 2 and 3 for the 1998-2000 period, as well as Figs. 5 and 6 in this article for 2008-2010.

${ }^{9}$ E.g. Bergek et al. 2008; Carlsson et al. 2002; Ergas 1986, 1987; Edquist (ed) 1997; Etzkowitz and Leydesdorff 2000; Fagerberg et al. (eds) 2005; Foray (ed) 2009; Freeman 1987, 1991, 1994, 1995, 2002; Lundvall (ed) 1992; Lundvall et al. 2002; Nelson (ed) 1993; Nelson 1995; Niosi 2002; Smith 2000, 2002.

${ }^{10}$ E.g. Agrawal and Cockburn 2002; Balconi et al. 2004; Bonaccorsi et al. 2014; Borsi 2005; Carlsson 2012; Cowan 2005; D’Este, and Patel 2007; D'Este et al. 2011; Feller et al. 2002; Havas 2004, 2009, 2010, 2011; Hemmert et al. 2014; Howells and Nedeva 2003; Inzelt 2004, 2010; Inzelt et al. 2009; Jensen et al. 2010; Laredo 2007, 2011; Laursen and Salter 2004; Mansfield and Lee 1996; Mazzoleni and Nelson 2007; Meyer-Kramer and Schmoch 1998; Mohnen and Hoareau 2003; Mora-Valentin et al. 2004; Mosoni-Fried and Szunyogh 2008; OECD 2001, 2002, 2008; Pavitt 1999; Rietzen and Soete 2011; Rosenberg and Nelson 1994; Schartinger et al. 2002; Technopolis 2012.

${ }^{11}$ Data used in this sub-section are taken from Eurostat and own calculations are also based on these data.

${ }^{12}$ This share has hardly changed between 2000 and 2012 in 14 countries (by not more than 5 percentage points), but there were some significant changes, too: an increase by 9 percentage points from an already high level in SE, by 17-22 percentage points in four countries (HU, LV, PT, SI), by 35-40 percentage points in BG and EE, while a decrease by $25-40$ percentage points in SK and RO.

${ }^{13}$ These data are presented and analysed in Havas (2010).

${ }^{14}$ Lithuania, Bulgaria and Romania were in the group of 'modest innovators' given their 2008-2009 performance, reflected in the Innovation Union Scoreboard 2010, Slovakia and Spain were among the 'moderate innovators', Slovenia and the UK were 'innovation followers', while Denmark, Finland, Germany Sweden formed the club of 'innovation leaders'. (UNU-MERIT 2011)

${ }^{15}$ These figures also indicate that either only a small number of firms reply to this question of the CIS questionnaire in several countries, and thus with a low share of 'votes' universities can take one of the top three positions, or they are more critical in some countries when the value of innovation co-operation methods are to be assessed than in other countries.

${ }^{16}$ The first of these types of measures were introduced already in the second half of the 1990s. For an overview of these measures see, e.g. Havas and Nyiri (eds) 2007, and for more details the annual ERAWATCH and TrendChart country reports, as well as the Joint Inventory of Policy Measures by ERAWATCH and TrendChart at http://erawatch. jrc.ec.europa.eu/erawatch/opencms/research_and_innovation/.

${ }^{17}$ For furhter details, including data from earlier periods, see Havas (2013), both on information sources for innovation and types of innovation co-operation. 
${ }^{18}$ As already mentioned, this paper is more of an essay drawing on selected results of various projects than a 'report' based on a single, 'purpose-designed' project focussing on B-A collaborations. Therefore, its 'sample' has not been constructed to underpin this article, either. Four to six firms have been interviewed in each sector, aiming at a qualitatively representative sample, that is, firms have been selected with different major features in terms of their size, ownership, age, technological level, etc. Spatial proximity between these firms and universities has not been a selection criterion, but practically in all cases, there has been at least one HEI in a close proximity (less than 30-50 km away). The dynamics of B-A co-operation has not been explicitly addressed during these semi-structured interviews, conducted in 2006-2012, but an overall observation can be made in that respect: for foreign-owned firms, it has taken some time to recognise that Hungarian HEIs and PROs can be valuable partners. In other words, learning in that sense, as well as building trust, has been an inevitable pre-condition to enter into B-A collaboration.

${ }^{19}$ Motivations for academics to be involved in B-A co-operations have not been explored in the interviews, on which this paper is based. Other pieces of work indicate that HEIs and PROs are interested in widening their networks, obtaining new ideas and additional revenues, modernising their equipment, as well as improving chances for their graduates on the labour market via B-A collaborations (Borsi 2005).

${ }^{20}$ The role of brokers and intermediaries in the Triple Helix is the topic of a forthcoming special issue of the THJ (the editor).

\section{Additional file}

Additional file 1: Translation of the abstract into Arabic.

\section{Acknowledgements}

This article draws on various projects; notably "Sectoral Systems of Innovation and Production in an Open Transition Economy" (OTKA, Hungarian Scientific Research Fund, contract No. T 046880 KGJ), Micro-Dyn (EU RTD FP6, contract No. 028868 CIT4), and AEGIS (EU RTD FP7, grant agreement No. 225134). Financial support provided by these projects is gratefully acknowledged. I am indebted to Balázs Lengyel, an anonymous referee, as well as the editor for their valuable comments.

Received: 15 July 2014 Accepted: 15 June 2015

Published online: 23 July 2015

References

Agrawal A, Cockburn IM (2002) University Research, Industrial R\&D, and the Anchor Tenant Hypothesis. NBER Working Paper Series 9212

Arnold E, Busch N, Fayl G, Guy K (2007) Programme monitoring at NKTH: principles and a pilot exercise. Report. NKTH, Budapest

Arrow K (1962) Economic welfare and the allocation of resources for invention. In: Nelson RR (ed) The Rate and Direction of Inventive Activity. Princeton University Press, Princeton, NJ, pp 609-625

Balconi M, Breschi S, Lissoni F (2004) Networks of inventors and the role of academia: an exploration of Italian patent data. Res Policy 33:127-145

Balconi M, Brusoni S, Orsenigo L (2010) In defence of the linear model: an essay. Res Policy 39:1-13

Baumol W (2002) The free-market innovation machine: analyzing the growth miracle of capitalism. Princeton University Press, Princeton, NJ

Baumol W, Litan R, Schramm C (2007) Good capitalism, bad capitalism, and the economics of growth and prosperity. Yale University Press, New Haven, CT

Bergek A, Jacobsson S, Carlsson B, Lindmark S, Rickne A (2008) Analyzing the functional dynamics of technological innovation systems: a scheme of analysis. Res Policy 37:407-429

Bonaccorsi A, Colombo M, Guerini M, Rossi Lamastra C (2014) How universities contribute to the creation of knowledge-intensive firms: detailed evidence on the Italian case. In: Bonaccorsi A (ed) Knowledge, diversity and performance in European higher education: A changing landscape. Edward Elgar, Cheltenham, pp 205-230

Borsi B (2005) A vállalatok és kutatóhelyek közötti kapcsolatok innovációs hatása Magyarországon (The innovation impact of science and industry relations in Hungary). Külgazdaság 49:37-57 
Bush V (1945) Science: the Endless Frontier. U.S. Government Printing Office, Washington, D.C., http://www.nsf.gov/od/ Ipa/nsf50/vbush1945.htm. Accessed 19 September 2013

Caraça J, Lundvall B-Å, Mendonça S (2009) The changing role of science in the innovation process: from Queen to Cinderella? Technol Forecast Soc Chang 76:861-867

Carlsson B (2012) Knowledge flows in high-tech industry clusters. Mimeo. Case Western Reserve University, Cleveland, Ohio

Carlsson B, Jacobsson S, Holmén M, Rickne A (2002) Innovation systems: analytical and methodological issues. Res Policy 31:233-245

Castellacci F (2008) Technological paradigms, regimes and trajectories: manufacturing and service industries in a new taxonomy of sectoral patterns of innovation. Res Policy 37:978-994

Cowan R (2005) Universities and the knowledge economy. MERIT-Infonomics Research Memorandum series No. 2005-027

D'Este P, Patel P (2007) University-industry linkages in the UK: what are the factors underlying the variety of interactions with industry? Res Policy 36:1295-1313

D'Este P, Guy F, lammarino S (2011) Shaping the formation of university-industry research collaborations: what type of proximity does really matter? Papers in Evolutionary Economic Geography No. 11.06. Utrecht University, Urban \& Regional Research Centre, Utrecht

Di Stefano G, Gambardella A, Verona G (2012) Technology push and demand pull perspectives in innovation studies: current findings and future research directions. Res Policy 41:1283-1295

Dodgson M, Rothwell R (eds) (1994) The Handbook of Industrial Innovation. Edward Elgar, Cheltenham

Dodgson M, Hughes A, Foster J, Metcalfe S (2011) Systems thinking, market failure, and the development of innovation policy: the case of Australia. Res Policy 40:1145-1156

Dosi G (1988) Sources, procedures and microeconomic effects of innovation. J Econ Lit 24:1120-1171

Dosi G, Freeman C, Nelson RR, Silverberg G, Soete L (eds) (1988) Technical Change and Economic Theory. Pinter, London

EC (2004) Innovation in Europe: results for the EU, Iceland and Norway. Office for Official Publications of the European Communities, Luxembourg

EC (2013a) Research and Innovation Performance in EU Member States and Associated Countries: Innovation Union Progress at Country Level. doi:10.2777/82363. http://ec.europa.eu/research/innovation-union/pdf/state-of-theunion/2012/innovation_union_progress_at_country_level_2013.pdf. Accessed 9 June 2013

EC (2013b) State of the Innovation Union 2012: Accelerating Change. doi:10.2777/70070. http://ec.europa.eu/research/ innovation-union/pdf/state-of-the-union/2012/state_of_the_innovation_union_report_2012.pdf. Accessed 24 June 2013

Edquist C (ed) (1997) Systems of innovations: technologies, institutions and organizations. Pinter, London

Edquist C (2011) Design of innovation policy through diagnostic analysis: identification of systemic problems or (failures). Ind Corp Chang 20:1725-1753

Ergas H (1986) Does technology policy matter? Centre for European Policy Studies, CEPS Papers No. 29, Brussels

Ergas H (1987) The importance of technology policy. In: Dasgupta P, Stoneman P (eds) Economic Policy and Technological Performance. Cambridge University Press, Cambridge, pp 51-96

Ernst \& Young and GKI (2010) A Kutatási és Technológiai Innovációs Alap 2004.01.01 - 2009.12.31. közötti múködésének átfogó értékelése (Comprehensive assessment study about the operation of the Research and Technology Innovation Fund (KTIA) 01.01.2004 - 31.12.2009). NKTH, Budapest

Etzkowitz H, Leysdorff L (2000) The dynamics of innovation: from National Systems and 'Mode 2' to a Triple Helix of university-industry-government relations. Res Policy 29:109-123

Etzkowitz H, Webster A, Gebhardt C, Cantisano Terra BR (2000) The future of the university and the university of the future: the evolution of ivory tower to entrepreneurial paradigm. Res Policy 29:313-330

Fagerberg J, Mowery DC, Nelson RR (eds) (2005) The Oxford Handbook of Innovation. Oxford University Press, Oxford

Fagerberg J, Fosaas M, Bell M, Martin B (2011) Christopher Freeman: social science entrepreneur. Res Policy 40:897-916

Fagerberg J, Landström H, Martin B (2012) Innovation: exploring the knowledge base. Res Policy 41:1132-1153

Feller I, Ailes CP, Roessner JD (2002) Impacts of research universities on technological innovation in industry: evidence from engineering research centers. Res Policy 31:457-474

Foray D (ed) (2009) The New Economics of Technology Policy. Edward Elgar, Cheltenham

Freeman C (1987) Technology and Economic Performance: Lessons from Japan. Pinter, London

Freeman C (1991) Networks of innovators, a synthesis of research issues. Res Policy 20:499-514

Freeman C (1994) The economics of technical change: a critical survey. Camb J Econ 18:463-514

Freeman C (1995) The 'National System of Innovation' in historical perspective. Camb J Econ 19:5-24

Freeman C (2002) Continental, national, and sub-national innovation systems - complementarity and economic growth. Res Policy 31:191-211

Freeman C, Soete L (1997) The Economics of Industrial Innovation (3rd edition). Pinter, London

GKM (2008) Ministry of Economy and Transport's Strategy for the Development of Small and Medium-sized Enterprises (2007-13), mimeo. Ministry of Economy and Transport, Budapest

Godin B (2006) The Linear Model of Innovation: The Historical Construction of an Analytical Framework. Sci Technol Hum Values 31:639-667

Godin B (2008) The moral economy of technology indicators. In: Hirsch-Kreinsen H, Jacobson D (eds) Innovation in Low-Tech Firms and Industries. Edward Elgar, Cheltenham, pp 64-84

Hall BH, Rosenberg N (eds) (2010) Economics of Innovation. North-Holland, Amsterdam

Havas A (2004) A nemzeti innovációs rendszer erősitése: Elméleti keret, nemzetközi összehasonlítás és gazdaságpolitikai javaslatok (Strengthening the national innovation system). mimeo, MTA KTI, Budapest http://mta.hu/fileadmin/ news/files/644/vkill2.pdf

Havas A (2009) Magyar paradoxon? A gyenge innovációs teljesítmény lehetséges okai (A Hungarian Paradox? Potential reasons for a poor innovation performance). Külgazdaság 53:74-112

Havas A (2010) A vállalatok és a közfinanszírozású kutatóhelyek K + F és innovációs együttmüködése Magyarországon (RTDI co-operation of firms and publicly financed R\&D organisations in Hungary). Felsőoktatási Múhely 4:57-72 
Havas A (2011) A Hungarian paradox? Poor innovation performance in spite of a broad set of STI policy measures. Triple Helix 9th International Conference, Silicon Valley: Global Model or Unique Anomaly? Stanford University, 11-14 July 2011

Havas A (2013) The need for multiple methods to map, and more refined policy tools to promote, business-academia collaborations: The case of Hungary. Triple Helix 11th International Conference, Bringing businesses, universities and governments together to co-innovate and solve economic, social and technological challenges, University College London, July 8-10, 2013

Havas A, Nyiri L (eds) (2007) National system of innovation in Hungary: Background report for OECD Country Review 2007/2008. NKTH, Budapest

Hemmert M, Bsieler L, Okamoro H (2014) Bridging the cultural divide: trust formation in university-industry research collaborations in the US, Japan, and South-Korea. Technovation 34:605-618

Hirsch-Kreinsen H, Jacobson D, Laestadius S (eds) (2005) Low Tech Innovation in the Knowledge Economy. Peter Lang, Frankfurt

Howells J, Nedeva M (2003) The international dimension to industry-academic links. Int J Technol Manag 25:5-17

Inzelt A (2004) The evolution of university-industry-government relationships during transition. Res Policy 33:975-995 Inzelt A (2010) Collaborations in the Open Innovation Era. In: Ekekwe N (ed) Nanotechnology and Microelectronics: Global Diffusion. Economics and Policy. Information Science Reference, IGI Global, Hershey, New York, pp 61-86

Inzelt A, Schubert A, Schubert M (2009) Egyetemi és gyakorlati szakemberek együttmúködése (Co-operation of university staff and practitioners). Educatio 18:32-49

Jensen R, Thursby J, Thursby MC (2010) University-Industry Spillovers, Government Funding, and Industrial Consulting NBER Woking Paper 15732

Klevorick AK, Levin RC, Nelson RR, Winter SG (1995) On the sources and significance of interindustry differences in technical opportunities. Res Policy 24:185-205

Kline SJ, Rosenberg N (1986) An overview of innovation. In: Landau R, Rosenberg N (eds) The Positive Sum Strategy: Harnessing Technology for Economic Growth. National Academy Press, Washington, pp 275-305

Laredo P (2007) Revisiting the third mission of Universities: toward a renewed categorisation of university activities? Higher Education Policy 20:441-456

Laredo P (2011) Positioning university-industry relations in Higher Education evolving environment. EIRMA Roundtable, January 28, 2011

Laursen K, Salter A (2004) Searching high and low: what types of firms use universities as a source of innovation? Res Policy 33:1201-1215

Lazonick W (2013) The Theory of Innovative Enterprise: Methodology, Ideology, and Institutions. In: Moudud JK, Bina C, Mason PL (eds) Alternative Theories of Competition: Challenges to the Orthodoxy. Routledge, London, pp 127-159.

Lipsey RG, Carlaw K (1998) Technology policies in neo-classical and structuralist-evolutionary models. STI Review, 22:31-73.

Lukasik J (2013) How to increase the contribution of universities to science and innovation. Presentation at the Round Table JRC-Universities, Brussels, 11 April 2013. https://ec.europa.eu/jrc/sites/default/files/20130411-jrc-universities-lukasik.pdf. Accessed 5 June 2013

Lundvall B-Å (ed) (1992) National systems of innovation: towards a theory of innovation and interactive learning. Pinter, London

Lundvall B-Å, Borrás S (1999) The globalising learning economy: implications for innovation policy. Office for Official Publications of the European Communities, Luxembourg

Lundvall B-Å, Johnson B, Andersen ES, Dalum B (2002) National systems of production, innovation and competence building. Res Policy 31:213-231

Malerba F (2002) Sectoral systems of innovation and production. Res Policy 31:247-264

Mansfield E, Lee J-Y (1996) The modern university: contributor to industrial innovation and recipient of industrial R\&D support. Res Policy 25:1047-1058

Martin B (2012) The evolution of science policy and innovation studies. Res Policy 41:1219-1239

Mazzoleni R, Nelson RR (2007) Public research institutions and economic catch-up. Res Policy 36:1512-1528

Meyer-Kramer F, Schmoch U (1998) Science-based technologies: university-industry interactions in four fields. Res Policy 27:835-851

Mohnen P, Hoareau C (2003) What type of enterprise forges close links with universities and government labs? Evidence from CIS2. Manag Decis Econ 24:133-145

Mora-Valentin EM, Montoro-Sanchez A, Guerras-Martin LA (2004) Determining factors in the success of R\&D cooperative agreements between firms and research organizations. Res Policy 33:17-40

Mosoni-Fried J, Zs S (2008) Kutatás és fejlesztés a közszférában (Research and development at universities and PROs). Közgazdasági Szemle 55:60-79

Mowery DC, Nelson RR (eds) (1999) Sources of industrial leadership: studies of seven industries. Cambridge University Press, Cambridge

Nelson RR (1959) The simple economics of basic scientific research. J Polit Econ 67:297-306

Nelson RR (ed) (1993) National innovation systems: a comparative study. Oxford University Press, Oxford

Nelson RR (1995) Recent evolutionary theorizing about economic change. J Econ Lit 33:48-90

Nelson RR, Winter SG (1982) An Evolutionary Theory of Economic Change. Harvard University Press, Cambridge, MA

Netwin K, Laser Consult K (2005) Értékelési zárójelentés - Kooperációs Kutatóközpontok Program: A vállalkozások versenyképességére gyakorolt hatások (Ex-post evaluation of the Co-operative Research Centres scheme), commissioned by the National Office for Research and Technology, June 2005

Niosi I (2002) National systems of innovation are 'x-efficient' (and x-effective): Why some are slow learners. Res Policy 31:291-302

OECD (1992) TEP: the key relationships. OECD, Paris

OECD (1998) New rationale and approaches in technology and innovation policy. Review, STI, No. 22

OECD (2001) Innovative networks: co-operation in national innovation systems. OECD, Paris

OECD (2002) Benchmarking industry-science relationships. OECD, Paris

OECD (2006) Government R\&D funding and company behaviour: measuring behavioural additionality. OECD, Paris

OECD (2008) OECD reviews of innovation policy: Hungary. OECD, Paris

Pavitt K (1984) Sectoral patterns of technical change: towards a taxonomy and theory. Res Policy 13:343-373

Pavitt K (1999) Technology, management and systems of innovation. Edward Elgar, Cheltenham 
Peneder M (2010) Technological regimes and the variety of innovation behaviour: creating integrated taxonomies of firms and sectors. Res Policy 39:323-334

Rietzen J, Soete L (2011) Research, higher education and innovation: redesigning multi-level governance within Europe in a period of crisis. UNU-MERIT Working Paper Series No. 2011-056

Rosenberg N, Nelson RR (1994) American universities and technical advance in industry. Res Policy 23:323-348

Schartinger D, Rammer C, Fischer MM, Fröhlich J (2002) Knowledge interactions between universities and industry in Austria: sectoral patterns and determinants. Res Policy 31:303-328

Smith K (2000) Innovation a s a systemic phenomenon: rethinking the role of policy. Enterprise Innovation Management Studies 1:73-102

Smith K (2002) What is the 'knowledge economy'? Knowledge intensity and distributed knowledge bases. UNU/INTECH Discussion Paper Series 2002-6

Technopolis (2012) Catalysing Innovation in the Knowledge Triangle: Practices from the EIT Knowledge and Innovation Communities. http://eit.europa.eu/sites/default/files/EIT_publication_Final.pdf. Accessed 5 June 2013

UNU-MERT (2011) Innovation Union Scoreboard 2010. http:/ec.europa.eu/research/innovation-union/pdf/iu-scoreboard-2010_en.pdf. Accessed 13 July 2014

Von Hippel E (1988) The sources of innovation. Oxford UP, Oxford

Von Tunzelmann GN (1995) Technology and industrial progress: the foundations of economic growth. Edward Elgar, Aldershot

Submit your manuscript to a SpringerOpen ${ }^{\circ}$ journal and benefit from:

- Convenient online submission

- Rigorous peer review

- Immediate publication on acceptance

- Open access: articles freely available online

- High visibility within the field

Retaining the copyright to your article

Submit your next manuscript at $\gg$ springeropen.com 